\title{
Tax Dispute Settlement Analysis On The Implementation Of Transfer Pricing in Transactions Between Affiliated Companies Using Advance Pricing Agreement (APA) Or Mutual Agreement Procedure (MAP) In Indonesia
}

\author{
Desiana*, Wardiyana** $^{* *}$ \\ *Tax Consultant, Batam \\ *Tax Consultant, Jogjakarta \\ DOI: 10.29322/IJSRP.11.07.2021.p11565 \\ http://dx.doi.org/10.29322/IJSRP.11.07.2021.p11565
}

\begin{abstract}
The purpose of this study is to analyze the implementation of Advance Pricing Agreement (APA) Approach and Mutual Agreement Procedure (MAP) Approach to settle the tax dispute. This research is a library research. This study concludes that the APA or MAP do help the taxpayer to avoid or settle the tax dispute over transfer pricing.
\end{abstract}

Index Terms- tax dispute, APA, MAP

\section{A. INTRODUCTION}

The more advanced and rapid development of the times and technology have a positive impact on business development. The increasing number of multinational companies that exist and interact with each other to support the progress of their business becomes increasingly limitless with the help of technology. The more companies, the more taxpayers, the more the possibility of tax disputes. Transactions between companies can clearly be seen and are increasingly. Transaction with affiliated companies occurring both for transactions of goods and services. How a company in a group or among its members make sales or purchases of goods or services is often a concern in taxation issues. Pricing for various transactions between these companies is often a dispute in taxation due to differences of opinion between the tax authorities and taxpayers.

According to Mardiasmo (2008), transfer pricing is the determination of prices for various transactions between members (divisions). Transfer pricing by affiliated companies is driven by tax reasons to minimize the amount of tax that must be paid. The company sets a lower or higher selling price and transfers the profits earned to a company domiciled in a country that applies a low tax rate. The existence of the issue of applying transfer pricing that is not foreign to multinational companies conducting international transactions has resulted in tax corrections by the tax authorities which are not fully approved by the company as taxpayers. In Indonesia, transfer pricing is regulated in Article 18 of Law Number 36 of 2008 concerning Income Tax. In the issue of transfer pricing, there are two basic things that are of concern, namely affiliation or special relationship and fairness or arm's length principle.

Taxes are the main source of state revenue and the largest source of development financing in Indonesia. In line with this significant contribution and strategic position, the tax sector must be managed in such a way that this sector has high reliability in many ways, including in dispute resolution and legal certainty (Budiono, 2005). Transfer pricing transactions are legal transactions, but in practice many companies abuse this application to avoid taxes. Tax avoidance is not desired by the government because it can reduce tax revenue. Due to this reason, the Directorate General of Taxes is authorized to do tax audit and re-determine the amount of taxable income for taxpayers who have special relationships with other taxpayers (multinational companies). The purpose of the tax audit is to see how much tax should be paid if the transactions is not affected by special relationships. The fairness of this transaction is test by using the price comparison method between independent parties, the resale price method, the cost-plus method, or another method. But besides that, it cannot be denied that multinational companies play an important role in encouraging economic growth, especially in developing countries.

When a tax dispute occurred between the taxpayer and the tax authorities, the taxpayer can seek legal remedies to resolve the dispute. Settlement of tax disputes can be reached through objections and settlements through the judiciary. However, dispute resolution through objections is still considered less objective because the decision maker is still part of the tax authorities themselves (tax officials) so they are often doubted. According to Hidayah (2018), tax dispute resolution in Indonesia takes more than 36 months to obtain legal certainty. This period of time is considered quite long, so it is advisable to carry out a transformation through Alternative Dispute Resolution (ADR) such as mediation in the resolution of Indonesian tax disputes. 
According to Khalimi (2017) there is a need for non-ministerial government agencies that have the task of handling objections and being an independent mediator of taxpayer disputes and the Directorate General of Taxes. Thus, it is hoped that if the dispute can be resolved more quickly, the taxpayer does not need to spend a fairly expensive cost which is quite burdensome for the company.

\section{B. CONCEPTUAL FRAMEWORK}

A multinational company is a public or private company that has part or all of its subsidiaries or affiliated divisions in at least one other country (Reese, Henneberry \& Russell, 1989). Transfer pricing is the process of setting prices for goods or services (output) between business units. In order to be successful in achieving the objectives of the company, a manager must consider taxation and non-taxation criteria in transfer pricing decisions. In determining the pricing methodology there are several variables that need to be considered, namely corporate strategic objectives, cash flow management, performance measurement, and organizational culture. Externally, income tax factors, economic conditions, customs duties, capital restrictions and foreign exchange differences are also factors that companies need to consider in determining transfer pricing (Martinson, Englebrecht \& Mitchell, 1999).

The OECD (2010) in the OECD Transfer Pricing Guidelines defines the arm's length principle as the principle of fairness and business practice. According to this, transactions carried out by related parties should be equal or comparable to transactions made by non-related parties. Based on the arm's length principle, multinational companies in the group will be treated as separate entities and not seen as a single business entity (Darussalam \& Septriadi \& Bawono, 2013).

According to Martinson et al. (1999) the eight key questions that need to be considered by companies to assess the audit risk of transfer pricing is:

1. Do comparable open market or arm's-length transactions exist?

2. How do the parent and subsidiaries compare on a value added basis?

3. Are combined profits of parent and subsidiaries shared in proportion to their contributions?

4. Is the same transfer pricing methodology used for all inter-company transfers?

5. Does the MNC's documentation and reporting requirements justify the transfer price used?

6. Will the corporation's transfer price meet the benchmark set by the tax authority?

7. Should the MNC consider entering into an Advanced Pricing Agreement with the IRS?

8. If a unilateral Advanced Pricing Agreement already exists, should it be expanded into bilateral agreement?

According to Anandarajan, McGhee, and Curatola (2007), several transfer pricing techniques that can be used by multinational companies are as follows:

1. $\quad$ Market price (market price)

The price used to sell to external customers.

2. $\quad$ Price based on cost (cost based price)

The cost-based method is used when market prices are unavailable or difficult to determine.

3. Resale price (resale price method)

Determination of the selling price after deducting costs for sales.

4. Profit split method

Determination through joint profit sharing on related party transactions using the risk profile basis.

5. The net profit method (net margin method)

comparing the percentage of net operating profit against expenses, sales, assets, or other basis for affiliated party transactions with the percentage of net operating profit earned on comparable transactions with non-affiliated parties.

According to Park (1997) Advance Pricing Agreements (APA) is a procedure to obtain prior approval from the tax authorities on the transfer pricing method to be used by taxpayers. Martinson and McKee (2001) state that the APA allows companies to propose certain transfer prices without risking being challenged or examined by the relevant authorities. In many countries there is a difference between the implementation of applicable law and the law that should exist. Because of this inequality, affiliated companies can take advantage of the tax and legal loopholes from this situation. According to the study, the APA procedure simplifies the process and accelerates the tax payment process.

According to Ardianto (2009), some of the benefits derived from the implementation of APA are as follows:

1. Protracted disagreements between taxpayers and tax authorities can be avoided. The APA process is an efficient forum for resolving issues related to complex international business practices and controversial transfers of goods and services between countries.

2. Mutual understanding and cooperation between taxpayers and tax authorities increases when joint discussions and negotiations are carried out, replacing hostile actions that usually follow examinations. APA encourages the flow of information from parties related to the APA process so that practical and acceptable results are obtained.

3. When compared with inspection, the amount of information requested is generally less, but the quality of the information produced is improved. 
4. The processes involved in the authority of the tax authorities could be clearer. Furthermore, the traditional problems associated with double-taxation cases can be avoided by bilateral or multilateral APAs.

5. Taxpayers acquire substantial capacity regarding how transfer pricing activities are treated for tax purposes, and in the event that there is a collective agreement from one or more tax treaties, how transfer pricing activities are treated by the tax authorities of foreign countries.

6. Parties involved in APA get better fiscal management because each one better estimates costs, including tax liability and compliance costs.

According to Cai and Zhang (2018), the Mutual Agreement Procedure (MAP) is an exclusive method in resolving international tax disputes. On the other hand, according to this study, the MAP method can cause agency costs. In article 25 paragraph 1 of the OECD model, it can be concluded that if an individual and corporate tax subject is subject to tax or will be subject to tax that is not in accordance with the provisions of the Tax Treaty, the tax subject can file a Mutual Agreement Procedure. MAP is a dispute resolution solution outside the realm of domestic dispute resolution, such as objections or appeals.

MAP or the procedure for mutual agreement is basically a communication forum between 2 (two) competent authorities in the context of implementing P3B. MAP is a special procedure that begins to function if there is a case of tax imposition that is not in accordance with or contrary to the Tax Treaty. The tax imposition can be corrected through the MAP, as long as it concerns the application of the relevant P3B. So this forum can be used by taxpayers to seek protection if they feel they are being treated not in accordance with the provisions in the Tax Treaty by competent officials from other countries (Surahmat, 2011). DDTC News (2019) informs that nearly 75\% of MAP transfer pricing cases were closed with the completion of a full or partial tax agreement not in accordance with the tax agreement, 5\% of which were granted unilateral relief, and 5\% were resolved through domestic remedies (domestic remedy).

\section{RESEARCH METHOD}

The approach used in this paper is a literature-based writing approach. Conceptual approach is used in analyzing the problem. The problem approach is carried out by conducting a study of the previous literature that is relevant to the problems discussed. Data collection uses secondary data in the form of books, journals, and regulations (library study).

\section{E. RESULT AND DISCUSSION}

Many of international tax dispute case occur due to the differences in interpreting of Double Taxation Avoidance Agreement (P3B) or tax treaty between the tax authorities and the taxpayer (WP). Companies with affiliated group also facing a tax dispute due to the different viewpoint to determine the arm's length. Objection or appeal process in domestic remedies is most commonly method used to settle the tax dispute in Indonesia.

When tax payer processing the objections and appeals there is some cost that not small need to be paid by companies. Court fees is one of the costs that have to be paid. Beside of that, the time need to consume to processed this settlement is not short. Waiting time is wasted by companies due to the process. As an example, taxpayers must wait for the tax authority's decision on their objections for up to 12 months. Next legal step or processed can be taken is appeal to the tax court if the taxpayer loses the objection case or disagree with the decision of objection process. Time given to the taxpayer to submit an appeal is three months from the date the objection decision is received. Although the hearing on the appeal case in the tax court is no later than 15 months after the appeal is filed, the issuance of the decision may exceed that period. Additional administrative sanction is one of the considerations for taxpayers. If taxpayer objection rejected or granted partially, a fine of 50 percent of the total tax based on the objection decision need to be paid by tax payer. For the appeal decision, if rejected or only partially granted, the taxpayer will be subject to additional administrative sanctions in the form of a fine of 100 percent of the total tax based on the appeal decision, which is not paid before filing the objection. So not only take time but also costs money.

Other approach can be better options to settle the tax dispute or prevent the audit of transfer pricing transactions. Applying for an Advance Pricing Agreements (APA) or Mutual Agreement Procedure (MAP) is considered better and save much costs. Tax payer can take prevention action by applying for APA. APA goal is to set a fair transaction price before the transaction carried out with one or more tax authorities. APA is a pre-agreed agreement, so tax payer and tax authorities agree to a price that will be used for affiliated transaction. APA can be unilateral or bilateral. Unilateral APA involving taxpayers with one tax authority. Bilateral APA involving taxpayers with two or more tax authorities. APA is not bound to double taxation avoidance agreement $(\mathrm{P} 3 \mathrm{~B})$. So, it can also be submitted for transactions with related parties in jurisdictions that are not bound by a tax treaty.

The APA method can increase certainty in planning affiliate transactions, avoiding double taxation and lengthy and highcost audits. From the tax authorities' point of view, APA puts forward a deeper understanding of the taxpayer's business model and information. However, if the APA fails to run, the taxpayer information that has been provided to the tax authorities can be used to conduct tax audits. In addition, not all countries have competent tax officials and formal regulations/guidelines to carry out APA procedures effectively. The costs incurred are also relatively high with procedures that tend to take quite a long time. 
The time need to wait for the decision on applying APA from Directorate General of Taxes is no later than 24 months. But it can also be extended for the next 24 months after the application is submitted by the taxpayer. The transfer price agreement under the APA framework is valid for the term of the affiliate transaction for the next five years. That's mean for the next five years companies save a lot cost and times compare to the litigation process.

Another approach to solve the tax dispute for transfer pricing transaction is Mutual Agreement Procedure (MAP). MAP is bonded by double taxation avoidance agreement (P3B). The deadline for submitting MAP is three years from the issuance of the tax assessment letter, the date of proof of payment, withholding or collection of income tax, and since the tax treatment deemed inappropriate is carried out. Directorate General of Taxes or tax authorities will research the information and related documents to determine whether to accept or reject the MAP application. If the MAP application is accepted, the Directorate General of Taxes will negotiate with the partner country tax authorities. Negotiations is processed maximum of 24 months after the application is received. MAP is negotiation instead of litigation. It's considered a good faith approach to settle the tax dispute. The APA and MAP costs does not cost to tax payer. Therefore, these two methods can help companies save on court costs if they file an objection or appeal.

Based on Government Regulation No. 74 of 2011 in Indonesia, the MAP agreement will be the basis for Directorate General of Taxes to determine the decision of the taxpayer objection. MAP result is stronger than the objection result but the MAP process must be completed before the tax payer goes through the appeal process. If the MAP process runs concurrently together with an appealed in the tax court and the result of MAP comes out first, then it can be used as consideration by the panel of judges in deciding the appeal case. On the other hand, if the appeal decision comes out first, the MAP process will automatically stop or cannot be continued. MAP has advantages and disadvantages. The advantage is that the Director of Tax Regulations has the competence to produce the best solution for both parties to avoid double taxation. In addition, the burden of proof is borne by the party submitting the correction. The disadvantage of MAP is taxpayers are not directly involved in the implementation of the MAP. The process of MAP is carried out by the tax authorities in each country. In other words, MAP process could not let the taxpayer put all the effort by themselves like the appeal process.

\section{F. CONCLUSION}

Multinational companies in running their business and expanding to various countries will definitely involve determining transfer pricing as one of the company's policies. However, the transfer pricing policy chosen could be the trigger for the reason for tax audits that lead to international tax disputes. To prevent transfer pricing tax disputes, companies can use the Advance Pricing Agreements (APA) method, while for handling transfer pricing disputes that have occurred, companies can use the Mutual Agreement Procedure (MAP) method.

\section{REFERENCES}

[1] Anandarajan, A., McGhee, M., \& Curatola, A. P. (2007). A guide to international transfer pricing. Journal

33-39. doi:10.1002/jcaf.20338

[2] Ardianto, Y. (2009). Advance Pricing Agreement (APA) Di Indonesia. Jurnal Ilmiah Manajemen Bisnis. 9(3).187-202.

Budiono, Abdul Rachmad. (2005). Pengantar Ilmu Hukum, Malang: Bayu Media Publishing.

[3] Cai, Q., \& Zhang, P. (2018). A Theoretical Reflection on the OECD’s New Statistics Reporting Framework for the Mutual Agreement Procedure: Isolating, Measuring, and Monitoring. Journal of International Economic Law, 21(4), 867-884. doi:10.1093/jiel/jgy043

[4] Darussalam, Denny Septriadi, dan B. Bawono. (2013). Transfer Pricing: Ide, Strategi dan Panduan Praktis dalam Perspektif Pajak Internasional. Jakarta: Danny Darussalam Tax Center.

[5] DDTC News. (2019). OECD Rilis Statistik MAP 2018, Kasus Baru Transfer Pricing Terus Naik. https://news.ddtc.co.id/oecd-rilis-statistik-map-2018-kasusbaru-transfer-pricing-terus-naik-17114?page_y=800

[6] Hidayah, K. (2018). Indonesian Tax Dispute Resolution in Cooperative Paradigm Compared to United Kingdom and Australia. IOP Conf. Ser.: Earth Environ.Sci. 175 012203.Khalimi. (2017). Penyelesaian Sengketa Pajak melalui Keberatan dan Banding. Jurnal Penelitian Hukum Legalitas. 11(1). ISSN 14118564 .

[7] Mardiasmo. (2008). Perpajakan edisi Revisi, Yogyakarta: Andi Offset.

[8] Martinson, O. B., \& McKee, T. C. (2001). Staying Out of Trouble with Transfer Pricing. Journal of Corporate Accounting \& Finance, 13(1), 3947. doi: $10.1002 /$ jcaf. 1206

[9] Martinson, O. B., Englebrecht, T. D., \& Mitchell, C. (1999). How multinational firms can profit from sophisticated transfer pricing strategies. Journal of Corporate Accounting \& Finance, 10(2), 91-103. doi:10.1002/1097-0053(199924)10:2<91::aid-jcaf11>3.0.co;2s

[10] Min Park. (1997). U.S Advance Pricing Agreement: An Option to Resolve International Tax Dispute in Transfer Pricing Cases. International Area Review. $1(1)$.

[11] Organisation for Economic Cooperation and Development. 2010. OECD Model Tax Convention. Paris: OECD Publishing.

[12] Republik Indonesia. Undang-Undang No. 36 Tahun 2008 tentang Perubahan keempat Undang-Undang No. 7 tahun 1983 tentang Pajak atas Penghasilan.

[13] Reese, R. A., Henneberry, S. R., \& Russell, J. R. (1989). Transfer pricing in multinational firms: A review of the literature. Agribusiness, 5(2), 121-

137. doi:10.1002/1520-6297(198903)5:2<121::aid-agr2720050205>3.0.co;2-6

[14] Surahmat, R. (2011). Persetujuan Penghindaran Pajak Berganda (P3B), Suatu Kajian terhadap Kebijakan Indonesia. Jakarta: Salemba Empat.

This publication is licensed under Creative Commons Attribution CC BY.

http://dx.doi.org/10.29322/IJSRP.11.07.2021.p11565

WWW.ijsrp.org 


\section{AUTHORS}

First Author - Desiana, Tax Consultant, desianazhang@yahoo.com

Second Author - Wardiyana, Tax Consultant, wardiyana30@gmail.com

Correspondence Author - Desiana, Tax Consultant, desianazhang@yahoo.com 